\title{
Lausunnonantajat vuonna 2019
}

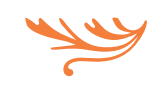

Vuonna 2019 Aikuiskasvatuksessa julkaistiin

12 vertaisarvioitua tiedeartikkelia. Lisäksi toimituskunta

käsitteli useita artikkelikäsikirjoituksia. Kiitämme

lämpimästi lausunnonantajia!

Annala Johanna, FT, dosentti, kasvatustieteiden ja kulttuurin tiedekunta, Tampereen yliopisto

Collin Kaija, KT, dosentti, kasvatustieteiden laitos, Jyväskylän yliopisto

Granholm Camilla, VTT, Folkhälsan, Helsingin yliopisto

Kristiina Hannukainen, FT, asiantuntija, Opintokeskus Sivis

Heiskanen Tuula, YTT, dosentti, Työelämän tutkimuskeskus, Tampereen yliopisto

Hilppö Jaakko, KT, tutkijatohtori, kasvatustieteiden osasto, Helsingin yliopisto

Himanka Juha FT, dosentti, filosofian yliopistonlehtori, yhteiskuntatieteellinen

tiedekunta, Lapin yliopisto

Helena Hirvonen, YTT, dosentti, yliopistonlehtori, Itä-Suomen yliopisto

Hytti Ulla, KTT, professori, Turun yliopiston kauppakorkeakoulu

Härkäpää Kristiina, FT, professori emerita, yhteiskuntatieteiden tiedekunta, Lapin yliopisto

Jolanki Outi, FT, tutkimuspäällikkö, dosentti, terveystieteet, yhteiskuntatieteiden tiedekunta, Tampereen yliopisto; yhteiskuntatieteiden ja filosofian laitos, Jyväskylän yliopisto

Kalalahti Mira, VTT, dosentti, kasvatustieteellinen tiedekunta, Helsingin yliopisto Kiilakoski Tomi, FT, dosentti, Nuorisotutkimusverkosto

Korhonen Vesa, KT, yliopistonlehtori, kasvatustieteiden ja kulttuurin tiedekunta, Tampereen yliopisto

Korhonen Maija, PsT, yliopistonlehtori, kasvatustieteiden ja psykologian osasto, Itä-Suomen yliopisto

Koskela Teija, KT, yliopistotutkija, opettajankoulutuslaitos, Turun yliopisto

Kosonen Toni, YTT, KM, tutkijatohtori, ohjauksen koulutus, Itä-Suomen yliopisto

Kumpulainen Kristiina, PhD, professori, kasvatustieteellinen tiedekunta, Helsingin yliopisto; vieraileva professori, Faculty of Education, University of British Columbia

Kuusipalo Paula, KM, väitöskirjatutkija, kasvatustieteiden ja kulttuurin tiedekunta, Tampereen yliopisto

Laiho Anne, KT, yliopistonlehtori, dosentti, kasvatustieteiden laitos, Turun yliopisto Lempiäinen Kirsti, professori, kasvatustieteiden tiedekunta, Lapin yliopisto

Mankki Ville KM, väitöskirjatutkija, kasvatustieteiden ja kulttuurin tiedekunta, Tampereen yliopisto 
Martikainen Soili, TkT, lehtori, riskienhallinta ja turvallisuusjohtaminen, Laureaammattikorkeakoulu

Niemi Anna-Maija, KT, Helsingin yliopisto

Niiranen Sonja, KT, yliopistonlehtori, kasvatustieteiden ja kulttuurin tiedekunta, Tampereen yliopisto

Nikkola Tiina, KT, FM, yliopistonopettaja, opettajankoulutuslaitos, Jyväskylän yliopisto Onnismaa Jussi, FT, työnohjaaja, dosentti, Werka kehitys Oy

Paloniemi Susanna, KT, yliopistonlehtori, kasvatustieteiden laitos, Jyväskylän yliopisto Peltola Raija, OTK, työnohjaaja, coach (PCC), partner, Tevere Oy

Postareff Liisa, KT, Hämeen ammattikorkeakoulu; dosentti, Turun yliopisto

Pulkki Jani, KT, tutkija, kasvatustieteiden ja kulttuurin tiedekunta, Tampereen yliopisto

Rautopuro Juhani, KT, dosentti, Koulutuksen tutkimuslaitos, Jyväskylän yliopisto

Salminen Hanna, VTT, viestintäjohtaja, valmentaja, Hengitysliitto ry.

Salo Petri, KT, professori, kasvatustieteiden ja hyvinvointitutkimuksen tiedekunta, Åbo Akademi

Taru Siekkinen, FT, YTM, tutkijatohtori, Koulutuksen tutkimuslaitos, Jyväskylän yliopisto

Silvonen Jussi, PsT, dosentti, kasvatustieteiden ja psykologian osasto, Itä-Suomen yliopisto

Suoranta Juha, KT, professori, yhteiskuntatieteiden tiedekunta, Tampereen yliopisto

Tuure Tammi, tutkijatohtori, kasvatustieteiden tiedekunta, Oulun yliopisto

Tervasmäki Tuomas, KM, kasvatustieteiden ja kulttuurin tiedekunta, Tampereen yliopisto

Vaahtera Touko, FT

Valkonen Emilia, FT, rehtori, Etelä-Karjalan kansalaisopisto

Varonen Mari, FM, verkkopedagogiikan suunnittelija, koulutuksen kehittämispalvelut, Jyväskylän ammattikorkeakoulu

Virtanen Anne KT, yliopistotutkija, Koulutuksen tutkimuslaitos, Jyväskylän yliopisto

\section{Refereepolitiikka}

Aikuiskasvatukseen tarjotut tiedeartikkelit käsitellään anonyymeina ja lähetetään mahdollisten muutospyyntöjen jälkeen kahdelle ulkopuoliselle asiantuntijalle arvioitavaksi. Arvioitsijat pysyvät kirjoittajille anonyymeinä, eikä kirjoittajan henkilöllisyyttä paljasteta arvioitsijoille.

Arvioinnin tavoite on antaa kirjoittajalle ehdotuksia ja neuvoja artikkelin parantamiseksi. Hyödyllisintä on rehellinen, kriittinen, käytännöllinen ja kannustava palaute. Referee arvioi seuraavia seikkoja:

- tutkimusaiheen merkityksellisyys, kiinnostavuus ja tärkeys

- kirjoittajan asiantuntemus
- tutkimusasetelma ja -menetelmät, lähdeaineisto, tutkimuksen toteutus ja käytetty tutkimuskirjallisuus suhteessa tutkimuskysymykseen

- tieteellinen taso

- sisällöllinen arvo ja uutuusarvo

- argumentoinnin vakuuttavuus

- kokonaisuus suhteessa otsikon ja aloituksen asettamiin odotuksiin

- esitystavan johdonmukaisuus

- luettavuus ja selkeys

- kuvioiden ja taulukoiden toimivuus. 